\title{
Ancestral Caddo Ceramic Vessel Sherd Studies: Buddy Calvin Jones Sites in East Texas
}

Timothy K. Perttula

Heritage Research Center, Stephen F. Austin State University

Follow this and additional works at: https://scholarworks.sfasu.edu/ita

Part of the American Material Culture Commons, Archaeological Anthropology Commons, Environmental Studies Commons, Other American Studies Commons, Other Arts and Humanities Commons, Other History of Art, Architecture, and Archaeology Commons, and the United States History Commons

Tell us how this article helped you.

This Article is brought to you for free and open access by the Center for Regional Heritage Research at SFA ScholarWorks. It has been accepted for inclusion in Index of Texas Archaeology: Open Access Gray Literature from the Lone Star State by an authorized editor of SFA ScholarWorks. For more information, please contact cdsscholarworks@sfasu.edu. 


\section{Ancestral Caddo Ceramic Vessel Sherd Studies: Buddy Calvin Jones Sites in East}

Texas

\section{Creative Commons License}

(c) (1) (8)

This work is licensed under a Creative Commons Attribution-NonCommercial 4.0 International License 


\section{Ancestral Caddo Ceramic Vessel Sherd Studies: Buddy Calvin Jones Sites in East Texas}

Timothy K. Perttula

\section{Introduction}

From the late 1940s to the early 1960s, Buddy Calvin Jones of Longview, Texas, identified and investigated archaeological sites across many counties in East Texas (Figure 1). Many of those sites were ancestral Caddo sites occupied from as early as ca. A.D. 850 to the early 1800s (see Jones 1957, 1968), and in his work he obtained surface collections of ceramic sherds from sites as well as large sherd assemblages and ceramic vessels from excavations in habitation deposits and Caddo cemeteries.

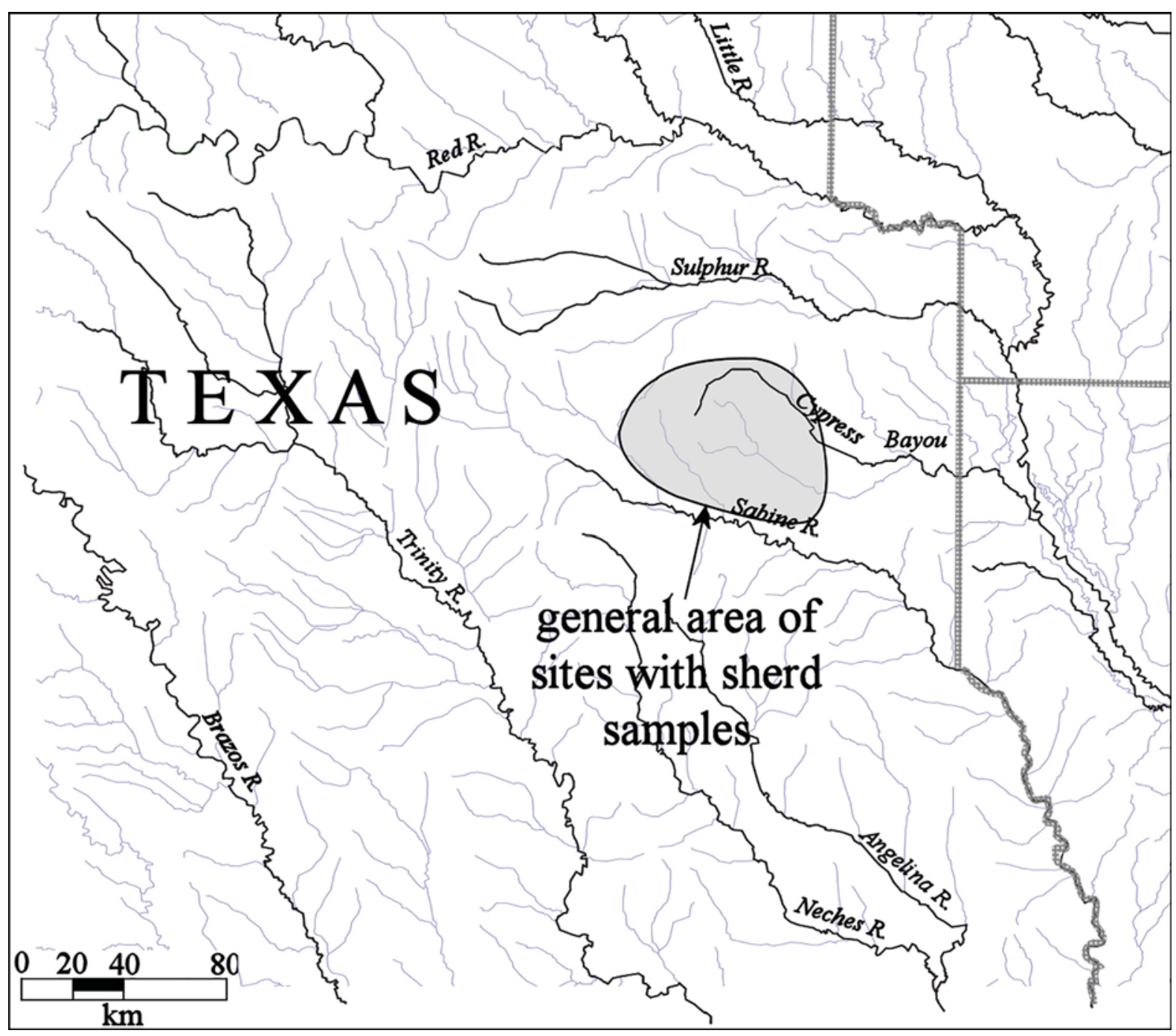

Figure 1. Area of East Texas with sherd samples collected by Buddy Calvin Jones. 
Jones published only a few papers on his investigations, but his expansive archaeological collections (accompanied by notes and documentation) were donated to the Gregg County Historical Museum in 2003, where they are available for study. Since that time, his various site specific collections of ancestral Caddo material culture remains have begun to be documented (Perttula 2006, 2009a, 2009b, 2011a, 2011c, 2011d, 2012, 2013 , 2014a, 2014b, 2014c, 2014d, 2014e; Perttula and Nelson 2007, 2013a, 2013b, 2014a, 2014b, 2014c, 2014d, 2014e; Perttula and Selden 2014a; Perttula et al. 2012d, 2013a, 2013b, 2014a, 2014b, 2014c, 2014d, 2014e), along with more extensive analyses of excavations of Caddo sites in the Little Cypress Creek basin in Upshur County, Texas (Perttula et al. 2012a, 2012b) and along the Red River in Red River County, Texas (Perttula et al. 2012c).

This article continues the analyses of the 100+ ancestral Caddo ceramic collections from sites in the Buddy Jones collection by focusing on several of the many previously unanalyzed sherd samples obtained from sites throughout much of East Texas. Jones did not publish analyses of any of these collections in his lifetime.

\section{Analytical Methods}

The stylistic analysis of the ceramic vessel sherds from East Texas Caddo sites collected by Buddy Calvin Jones in the 1950s and 1960s focuses on the definition of recognizable decorative elements on sherds from the fine wares (i.e., the engraved and red-slipped vessels, including carinated bowls and bottles) and utility wares (i.e., the coarse paste decorated vessels), usually cooking or storage jars and simple bowls. These wares are known to have been made and used differently, based on functional, technological, and stylistic analyses on numerous Caddo sherd assemblages in the broader East Texas region, with uses ranging from food service, cooking of food stuffs, as containers for liquids, and for plant food/ seed crop storage.

The analysis of the ceramic sherds (and any pipes from these sites) emphasizes the acquisition of information on the stylistic and technological character of the prehistoric Caddo ceramic assemblage. Attributes of the ceramics are then employed to establish the occupational history of the sites as reconstructed from ceramic stylistic analyses (particularly variation in decorative elements and motifs in both the utility ware and fine ware). When sherds large enough to exhibit overall design motifs are present in the assemblage, typological classifications are possible. In the absence of whole vessels or vessel sections large enough to discern typologically distinct decorative motifs, another way to distinguish subtle differences between relatively similar ceramics is to look at the technological variations found on individual sherds or groups of sherds from discrete contexts. Variations in key technological attributes such as vessel form and temper use in Caddo pottery in East Texas, and across the Caddo area, bear a direct relationship to the desired use of the pot (see Perttula 2000). Accordingly, sherds recovered from these sites can be characterized according to a suite of key technological attributes, as well as key decorative methods, motifs, and decorative elements.

More specifically, the following attributes were employed in the analysis of the ceramics from these East Texas sites: (a) temper, the deliberate and indeterminate materials found in the paste (Rice 1987:411), including a variety of tempers (grog or crushed sherds, burned bone, shell, or hematite) and "particulate matters of some size;" (b) although most of the sherds proved to be small and thus from indeterminate vessel forms, where sherds were large enough, vessel form categories that could be identified include open containers (bowls, compound bowls, and carinated bowls) and restricted containers, including jars and bottles.

Decorative methods present in these East Texas Caddo site ceramic sherd collections include engraving, incising, punctation, brushing, pinching, appliqué, and neck banding, and on certain sherds, combinations of decorative techniques (i.e., brushed-incised and brushed-appliqued, or incised-punctated sherds) created the decorative elements and motifs. Engraving was done with a sharp tool when the ves- 
sel was either leather-hard or after it was fired, while the other decorative techniques were executed with tools or fingers (incising, punctations, and pinching with wood or bone sticks or dowels), by adding strips of clay to the wet body (appliqué), using frayed sticks or grass stems (brushing) across the vessel surface, or corrugating vessel coils when the vessel was wet or still plastic to create a series of neck bands. Excising is considered a form of engraved decoration, where the clay is deliberately and closely marked/ scraped and carved away with a sharp tool, usually to create triangular elements or crescent-shaped elements separating or defining scrolls. Decorative comparisons are made between the fine wares (i.e., engraved, certain trailed vessel sherds, and red-slipped), utility wares (wet paste decorations), and plain wares (plain rims and plain body sherds; the latter admittedly can be from plain vessels as well as the undecorated portions of fine wares or utility wares, but the comparisons between these three categories still prove useful).

Ceramic stylistic or decorative elements defined and recognized on sherds from the East Texas sites simply represent one classification of different ways of decorating a vessel by the prehistoric Caddo peoples, and there is general consensus that shared styles are "the result of direct cultural transmission once chance similarity in a context of limited possibilities is excluded" (Dunnell 1978:199). Decorative elements represent distinct designs or design combinations (i.e., the breakdown of individual decorations within an overall design, as in a hatched triangle, circle, or tick marks) that can be identified on sherds and vessel sections (even if it is only a portion of the element), generally comparable to what Schambach et al. (n.d.) term a "recurrent feature of decoration" within each of the major decorative methods (e.g., incising, punctating, engraving, etc.) present in a Caddo ceramic assemblage. The design elements are defined at different levels of association, depending upon variations in the designs (e.g., the number and spacing of engraved lines on a rim), the location of the decoration (e.g., on the rim, body, on the vessel interior, etc.), and the method of decoration (e.g., horizontal vs. vertical brushing).

\section{Sites in East Texas with Ceramic Vessel Sherd Samples}

Other sherd samples from several sites collected by Buddy Jones in Gregg, Panola, and Rusk counties, Texas, have been previously analyzed and reported by Perttula (2016a-h) and Perttula et al. (2016). These include samples from the Grace Creek site (41GG33), Millsey Williamson (41RK3), C. D. Marsh (41HS269), and the Cherokee Lake site (41RK132). Herein, I discuss the results of the analysis of ceramic sherd assemblages from different sites in Cherokee, Gregg, Harrison, Marion, Panola, Rusk, Smith, Upshur, and Wood counties in East Texas (see Figure 1).

\section{Upshur County}

\section{Henry Williams site (41UR318)}

The Henry Williams site is a Late Caddo habitation and cemetery locale situated north and west of Gum Creek in the Little Cypress Bayou basin (Perttula et al. 2012b:Figure 107). Buddy Jones excavated the cemetery in 1954 and 1955.

The cemetery was situated in a cotton field, about $2.5 \mathrm{~m}$ above the Gum Creek floodplain on an alluvial terrace landform; several of the burials were found in a low-lying eroded area (with red clay exposed at the surface) in the edge of the floodplain itself. A total of 37 burials were excavated by Jones in the cemetery, in a number of east to northeast-oriented rows and clusters. The deceased individuals were accompanied with several kinds of funerary offerings, primarily ceramic vessels $(n=138)$ and arrow point caches/quivers $(n=110)$ (Perttula et al. 2012b:Table 4). All of the burials had ceramic vessels, two burials had ceramic pipes, eight burial had arrow point caches, three burials had tools (celts or a large chipped biface), and two burials had clay pigments. Total numbers of funerary offerings ranged from 1-45 items, with a mean of 8.0 offerings per burial. 
In addition to the cemetery, there were habitation deposits at the Henry Williams site that Jones collected ceramic sherds from in the early 1950s. These habitation deposits were west of the cemetery (Figure 2).

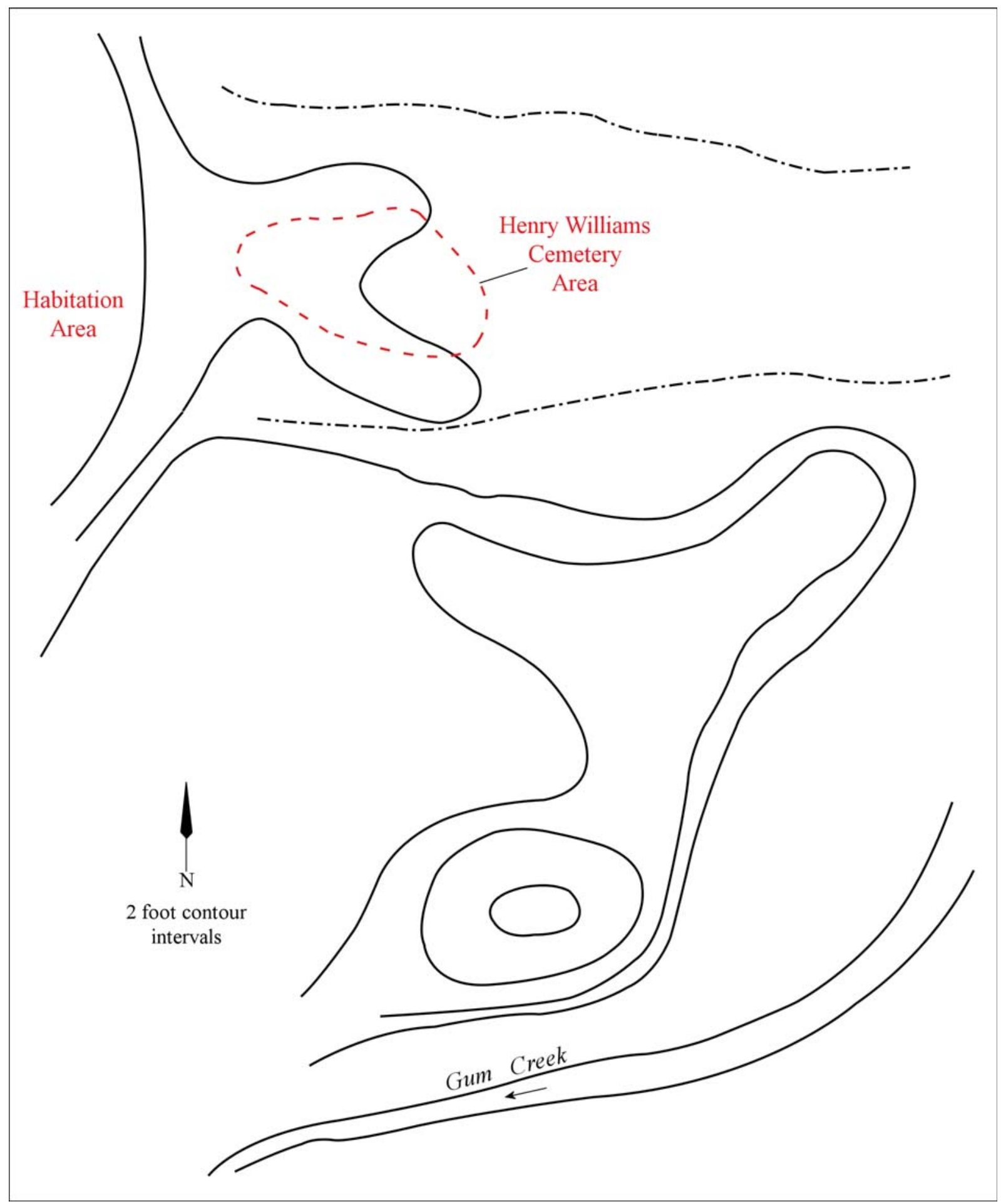

Figure 2. Map of the Henry Williams site (41UR318). 
Jones collected 252 ceramic sherds from plain ware, utility ware, and fine ware vessels in the habitation area at the Henry Williams site (41UR318). About 82 percent of the sherds are from grogtempered vessels and the remainder are from bone-tempered vessels (Table 1). The highest proportion of bone-tempered sherds are in the plain wares (23.4 percent).

Table 1. Ceramic sherd assemblage from the Buddy Jones collection from the Henry Williams site (41UR318).

\begin{tabular}{lccl}
\hline Ware & Grog-tempered & Bone-tempered & $\mathrm{N}$ \\
\hline Plain & 111 & 34 & 145 \\
Utility & 44 & 2 & 46 \\
Fine & 53 & 8 & 61 \\
\hline Totals & 208 & 44 & 252 \\
\hline
\end{tabular}

More than 54 percent of the utility ware sherds are from brushed vessels (Table 2). Another 8.7 percent of these sherds have brushed-appliqued or brushed-incised decorative elements. About 24 percent of the sherds have incised decorative elements, and appliqued (6.5 percent) and tool punctated (6.5 percent) decorative elements comprise the remainder of the utility ware sherds from the Henry Williams site.

Table 2. Decorative methods/elements in the utility ware sherds from the Henry Williams site (41UR318).

Decorative method/ Rim $\quad$ Body N

decorative element

Appliqued

appliqued nodes in rows

straight appliqued ridge

$\begin{array}{lll}- & 1 & 1 \\ - & 2 & 2\end{array}$

Brushed

overlapping brushed

parallel brushing

$\begin{array}{lll}- & 1 & 1 \\ - & 24 & 24\end{array}$

Brushed-Appliqued

parallel brushed-straight appliqued fillet

Brushed-Incised

parallel brushed-incised marks and lines

3

3

Incised

diagonal lines

diagonal opposed lines

opposed lines

parallel lines

straight line

$\mathrm{N}$


The brushed and brushed-incised sherds are from the bodies of Bullard Brushed jars, while the brushed-appliqued sherd may be from a Pease Brushed-Incised vessel. The one body sherd with rows of appliqued nodes is from a distinctly decorated Moore Noded vessel (see Webb 1959). The incised sherds have decorative elements consistent with those noted on Maydelle Incised jars (see Suhm and Jelks 1962), while the punctated rim and body sherds from the Henry Williams site may be from Mockingbird Punctated jars (see Perttula and Selden 2014b).

The fine ware sherds from the Henry Williams site include engraved sherds from bottles, engraved sherds from carinated bowls and bowls, and one unique red-slipped bottle with rows of circular punctates on the vessel body (Table 3). One of the engraved carinated bowl sherds (from a Taylor Engraved vessel) has an interior and exterior red-slipped surface, another engraved carinated bowl sherd (from a Ripley Engraved, var. McKinney vessel) has a white clay pigment rubbed in the engraved motif, and a third carinated bowl sherd (from a Ripley Engraved, var. Richey vessel) has a red clay pigment rubbed in the engraved lines.

Table 3. Decorative methods/elements in the fine ware sherds from the Henry Williams site (41UR318).

\begin{tabular}{llll}
\hline $\begin{array}{l}\text { Decorative method/ } \\
\text { decorative element }\end{array}$ & Rim & Body & N
\end{tabular}

Engraved-Bottles

curvilinear lines

curvilinear lines and cross-hatched zone

parallel lines

parallel lines and pendant open triangles

straight line with excised tick marks

$\begin{array}{lll}- & 1 & 1\end{array}$

$\begin{array}{lll}- & 1 & 1\end{array}$

$\begin{array}{lll}- & 2 & 2\end{array}$

$\begin{array}{lll}- & 1\end{array}$

Engraved-Bowls and Carinated Bowls

central circle element, excised bracket, and open

1

pendant triangle

central circle element and excised pendant triangle

central circle element, excised pendant triangles,

and lower scroll fill zone

curvilinear lines

excised bracket element

excised triangles

hooked arm scroll arms and excised bracket

horizontal lines under lip

horizontal lines, multiple

horizontal lines with excised pendant triangles

horizontal lines with excised pendant triangles and

1

central diamond element

horizontal lines with excised pendant triangles and

scroll fill zone

horizontal lines with excised linear tick marks

horizontal scroll and hooked arm element

horizontal lines, uppermost with excised pendant

triangle, and slanting scroll

horizontal and diagonal lines

parallel lines

$\begin{array}{lll}- & 1 & 1 \\ 3 & - & 3 \\ - & 2 & 2 \\ - & 1 & 1 \\ - & 1 & 1 \\ 1 & - & 1 \\ 7 * & - & 7 \\ 2 & 3 & 5 \\ 2+ & 2 & 4 \\ 2 & - & 2 \\ & & \\ 1 & - & 1 \\ & & 1 \\ 1 & - & 1 \\ - & 1 & 2 \\ 1 & - & \end{array}$


Table 3. Decorative methods/elements in the fine ware sherds from the Henry Williams site (41UR318), cont.

\begin{tabular}{|c|c|c|c|}
\hline $\begin{array}{l}\text { Decorative method/ } \\
\text { decorative element }\end{array}$ & Rim & Body & $\mathrm{N}$ \\
\hline \multicolumn{4}{|l|}{ Engraved-Bowls and Carinated Bowls, cont. } \\
\hline scroll with lower excised pendant triangles & - & 1 & 1 \\
\hline scroll with hooked arm element & - & $1 * *$ & 1 \\
\hline slanting scroll with central circle element & 1 & - & 1 \\
\hline slanting scroll and excised bracket element & - & 1 & 1 \\
\hline slanting scroll with excised linear tick marks & 1 & - & 1 \\
\hline $\begin{array}{l}\text { slanting scroll and horizontal line with excised } \\
\text { pendant triangle }\end{array}$ & 1 & - & 1 \\
\hline slanting scroll with hooked arm element & $1++$ & - & 1 \\
\hline straight line & - & 5 & 5 \\
\hline straight line with large excised pendant triangle & - & 1 & 1 \\
\hline triangular element and adjacent curvilinear lines & - & 1 & 1 \\
\hline \multicolumn{4}{|l|}{ Slipped-Punctated Bottles } \\
\hline circular punctated rows and ext. red-slipped & - & 1 & 1 \\
\hline Totals & 26 & 35 & 61 \\
\hline
\end{tabular}

*one rim has a suspension hole below the lip

**also red-slipped

+one with white pigment in engraved lines; ++one with red pigment in the engraved lines

The bottle sherds comprise 11.5 percent of the fine wares from the site, including the slipped-punctated bottle sherd. The other bottle sherds are likely from Ripley Engraved vessels with curvilinear lines on the vessel body, crosshatched zones (Figure 3a), parallel lines with open pendant triangles and/or an oval-shaped element (Figure 3b), and a bottle sherd with excised tick marks on a straight engraved line (Figure 3c; see Table 3).

The engraved carinated bowl and bowl sherds are almost exclusively from Ripley Engraved vessels, including those from vessels of several defined varieties (see Fields et al. 2014:Table 8.6). There are also two sherds from Taylor Engraved vessels in the assemblage (Figure 4a-b). One of the sherds has an interior and exterior red slip (Figure 4b).

The identified varieties of Ripley Engraved in the Henry Williams sherd assemblage include: var. McKinney ( $\mathrm{n}=10$ rim sherds and 5 body sherds, Figure 5a-b, d-g); var. McKinney-Enis Smith ( $\mathrm{n}=1$ body sherd, Figure 5c); var. Richey ( $\mathrm{n}=1$ rim sherd and 1 body sherd, Figure 6a, c); var. Galt ( $\mathrm{n}=1 \mathrm{rim}$ sherd, Figure $6 \mathrm{~b}$ ), and var. Gandy ( $\mathrm{n}=1$ rim sherd, Fig-

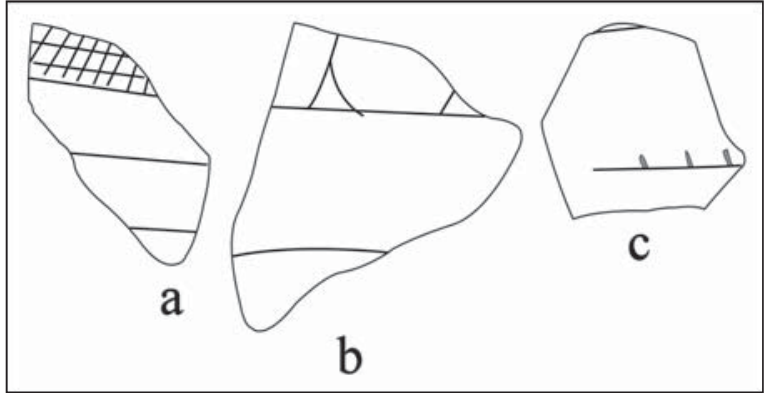

Figure 3. Selected examples of engraved bottle sherds from the Henry Williams site (41UR318).

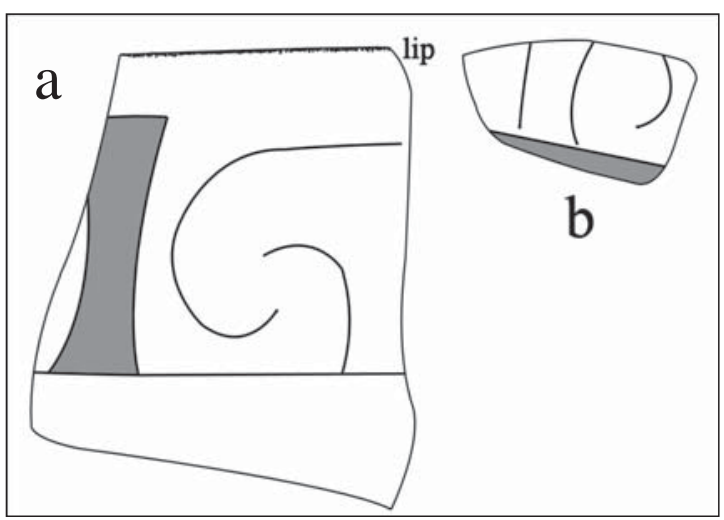

Figure 4. Taylor Engraved decorative elements on rim and body sherds from the Henry Williams site. 


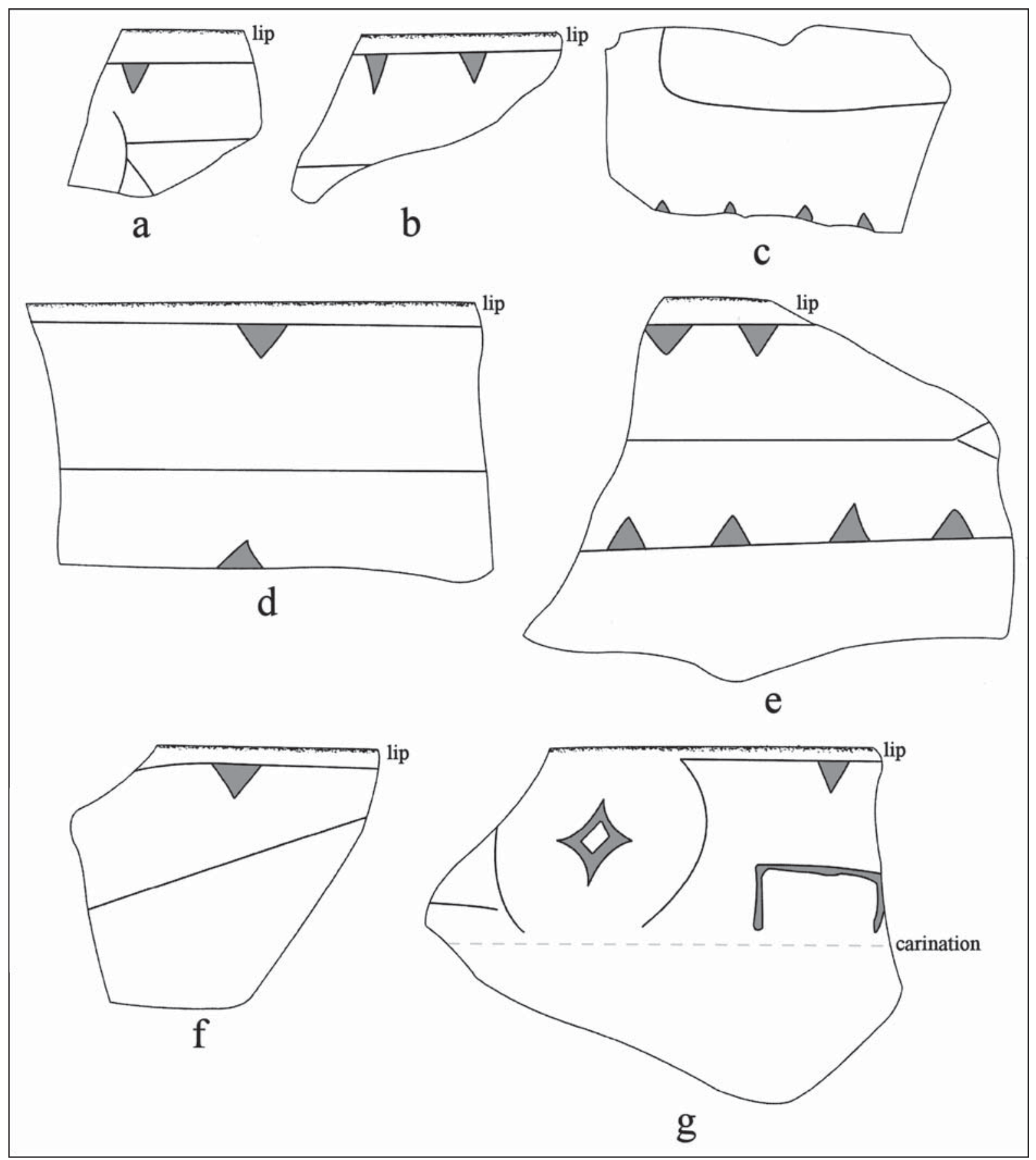

Figure 5. Selected examples of Ripley Engraved, var. McKinney and var. McKinney-Enis Smith decorative elements on sherds from the Henry Williams site.

ure 6d). The predominance of var. McKinney sherds in the habitation area ceramic assemblage at the Henry Williams site is not matched by the vessels from the cemetery (Perttula et al. 2012b:Table 9), where over 61 percent of the vessels are var. Gandy or cf. var. Gandy Ripley Engraved vessels; var. McKinney vessels account for only 3.8 percent of the fine ware vessels in the cemetery. Nevertheless, the majority of the burials at the Henry Williams site date to the late Titus phase (ca. A.D. 1550-1680), and it is suspected that the habitation area at the site also dates to some portion of this time period, but the habitation by Caddo peoples took place primarily after the cemetery was no longer in use, after ca. A.D. 1600. 


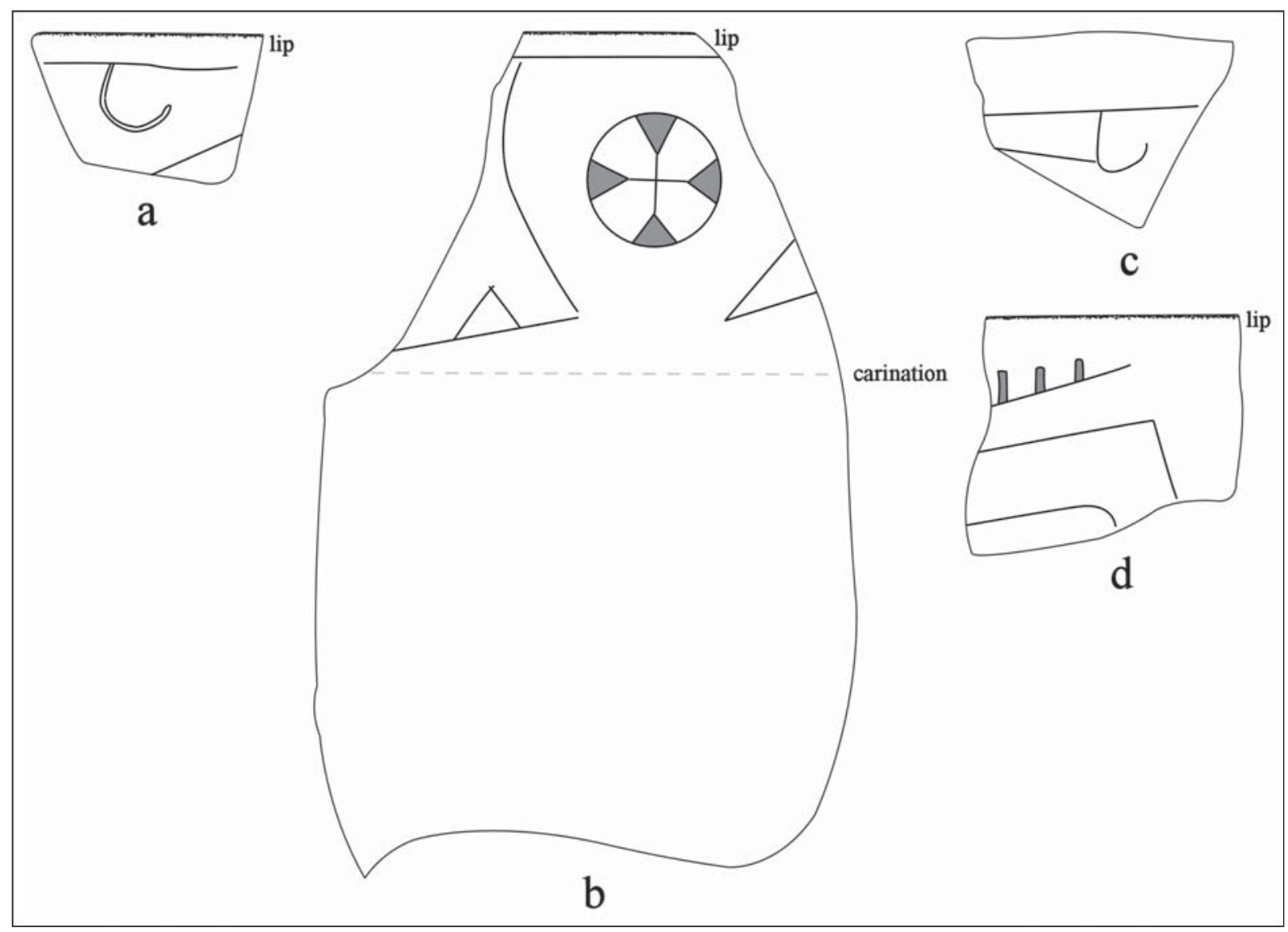

Figure 6. Selected examples of Ripley Engraved, var. Galt, var. Gandy, and var. Richey decorative elements on sherds from the Henry Williams site.

\section{Bottom Site}

There are five Caddo ceramic sherds from this site, all from grog-tempered vessels. Two are plain body sherds, two are brushed rim (horizontal brushed) and body (parallel brushed) sherds, and the other sherd is a body sherd with a straight engraved line. The brushed sherds are indicative of a ca. post-A.D. 1250 Caddo occupation at the site.

\section{Upshur County 1-3}

This Glade Creek site has 37 ceramic sherds: 17 plain ware (one rim and 16 body sherds); 18 utility ware; and two from fine ware vessels. About 70 percent of the sherds are from grog-tempered vessels and the remaining 30 percent are from bone-tempered vessels.

Ten of the utility ware sherds have parallel brushing marks, another-from a Pease Brushed-Incised or Bullard Brushed vessel - has parallel brushing marks with a row of tool punctations pushed through the brushing, and one body sherd has overlapping brushed marks with overlying opposed incised lines. The brushed and brushed-incised sherds are indicative of a ca. post-A.D. 1250 Caddo occupation at the site.

Two body sherds have rows of tool punctations, and three body sherds have rows of fingernail punctations. One sherd has a curvilinear incised line with tool punctated zones on either side of the incised line. 
One fine ware body sherd has a curvilinear engraved line, while the other fine ware sherd is a carinated bowl rim. It has a diagonal opposed engraved decorative element (Figure 7).

\section{Cypress Springs site (Upshur County 20)}

The 12 sherds from this Little Cypress Bayou site are from grog-tempered vessels. This includes four plain body sherds and one base sherd. The six utility ware sherds are comprised of three parallel brushed body sherds, a rim with tool punctated rows, another body sherd with closelyspaced parallel incised lines, and a body sherd with parallel incised lines overlain by parallel incised lines pitched in a different direction. The brushed sherds are indicative of a ca. post-A.D. 1250 Caddo occupation at the site. The one fine

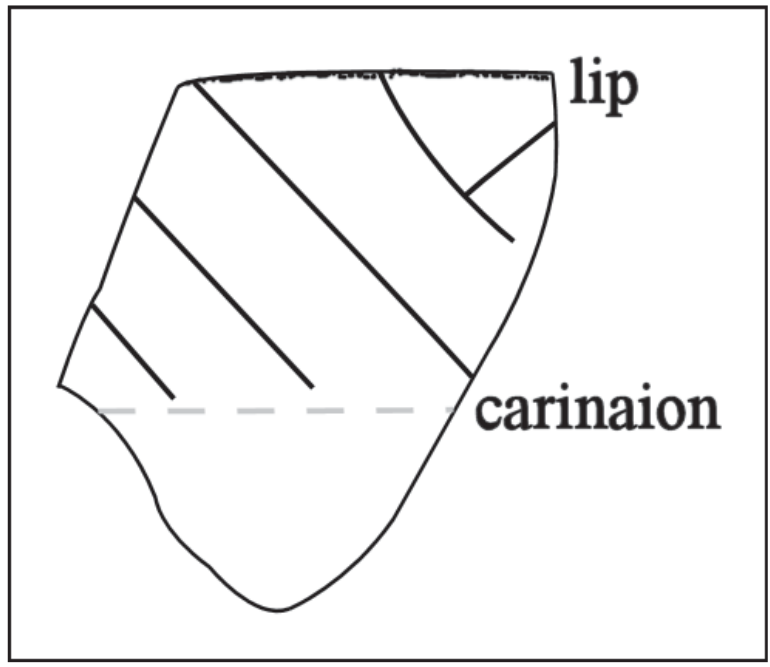

Figure 7. Engraved carinated bowl sherd from the Glade Creek site, Upshur County, Texas.

ware sherd is from a bottle, and has a curvilinear engraved line element.

\section{Upshur County 24}

There are only four ceramic sherds from this Caddo site in the Little Cypress Bayou basin. Three sherds are plain rim and body sherds from grog-tempered vessels, and the other sherd is a body sherd with parallel brushed-incised marks and lines. The brushed sherd is indicative of a ca. post-A.D. 1250 Caddo occupation at the site.

\section{Upshur County 26}

This site in the Little Cypress Bayou basin has seven decorated ceramic sherds, 86 percent from grog-tempered vessels. Five of the grog-tempered utility ware sherds have parallel brushed marks, and the other, probably from a Pease Brushed-Incised jar, has diagonal brushing marks adjacent to a straight appliqued fillet. The brushed and brushed-appliqued sherds are indicative of a ca. post-A.D. 1250 Caddo occupation at the site. The one fine ware sherd has a single straight engraved line.

\section{Upshur County 29}

This site in the Little Cypress Bayou basin, south of Lily Creek, has 28 plain and decorated sherds. More than 92 percent of the sherds are from grog-tempered vessels, and the remainder are from bone-tempered vessels; both of the bone-tempered sherds are plain body sherds.

Ten of the 15 decorated sherds are from utility ware vessels. Two rims, possibly from Mockingbird Punctated jars (see Perttula and Selden 2014b), have rows of tool punctations. Five body sherds have parallel brushing marks, another body sherd has parallel brushed-incised marks and lines, and two body sherds have parallel incised lines. The brushed and brushed-incised sherds are indicative of a ca. postA.D. 1250 Caddo occupation at the site.

Among the sherds from fine ware vessels are four rim or body sherds from engraved vessels and a exterior red-slipped bottle sherd. Another bottle body sherd has a single curvilinear engraved line. The one rim sherd has a single horizontal engraved line below the lip as well as a series of closely-spaced vertical engraved lines, probably panel dividers (Figure 8). The remaining body sherds with engraved decorative elements include one with parallel engraved lines and a body sherd from a carinated bowl with a single horizontal engraved line above the carination. 


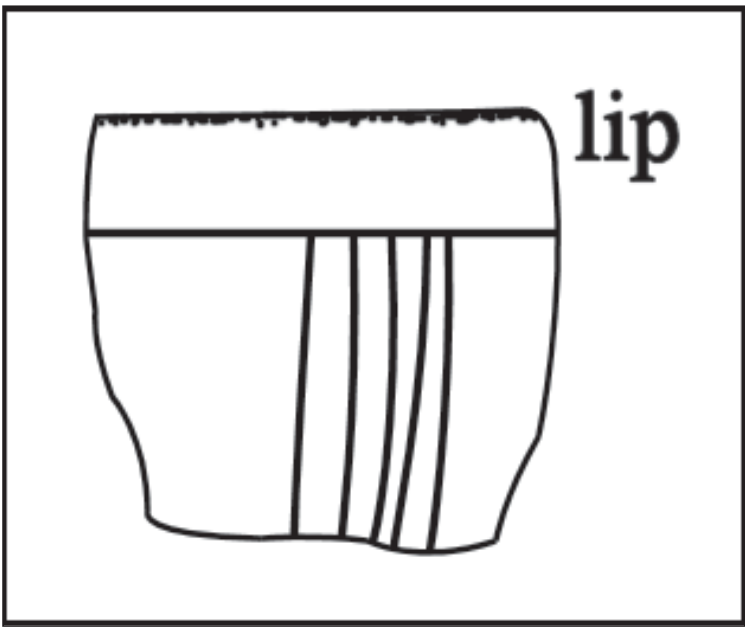

Figure 8. Engraved rim sherd from Upshur County 29 in the Buddy Jones collection.

\section{Upshur County 46}

There are only two ancestral Caddo ceramic vessel sherds from this site on Richmond Creek in the Big Cypress Creek basin; it is near the Riley site (41UR2). One is a plain bone-tempered base sherd, and the other is a grog-tempered body sherd with a single straight engraved line.

\section{Upshur County 66}

There are seven grog-tempered plain and utility ware sherds from the site. Two are plain body sherds, one has parallel incised lines, three have parallel brushing marks, and the last sherd has parallel brushed-incised marks and lines. The brushed and brushed-incised sherds are indicative of a ca. post-A.D. 1250 Caddo occupation at the site.

\section{Wood County}

\section{Farm Home Site}

The Farm Home site collection has 20 sherds from grog-tempered vessels. Twelve are plain body sherds, five sherds have parallel brushing marks, and another utility ware sherd has parallel incised lines; the presence of brushed sherds is indicative of a ca. post-A.D. 1250 Caddo occupation at the site. The one fine ware sherd is from a red-slipped bottle.

\section{Highway 80 Site}

The Highway 80 site is located about 200 m east of the Highway 80 bridge over Lake Fork Creek, and west of Hawkins, Texas. Jones collected sherds from the site in July 1961. More than 99 percent of the sherds are from grog-tempered vessels (Table 4), and 78 percent of the 36 decorated sherds are from utility ware vessels.

Table 4. Ceramic sherd assemblage from the Highway 80 site in Wood County, Texas.

\begin{tabular}{lccc}
\hline Ware & Grog-tempered & Bone-tempered & $\mathrm{N}$ \\
\hline Plain & 100 & 1 & 101 \\
Utility & 28 & - & 28 \\
Fine & 8 & - & 8 \\
\hline Totals & 136 & 1 & 137 \\
\hline
\end{tabular}

Most of the utility ware sherds, and the three utility ware rim sherds, have either punctated (54 percent of the utility wares) or incised-punctated (28.6 percent) decorative elements (Table 5). The incised-punctated sherds are probably from Canton Incised vessels with either incised zones filled with punctations (Figure 9a-b) or cross-hatched incised lines above a row of tool punctations at the rim-body juncture (Figure 9c). Other incised-punctated sherds have diagonal incised lines below a horizontal linear punctated row below the vessel lip (Figure 9d) or have parallel incised lines and a diagonal punctated row (Figure 9e). 
Table 5. Decorative methods/elements in the utility ware sherds from the Highway 80 site in Wood County, Texas.

Decorative method/

Rim Body N

decorative element

Appliqued

straight appliqued fillet

$\begin{array}{ccc}- & 1 & 1\end{array}$

\section{Incised}

parallel lines

straight line

$\begin{array}{lll}- & 1 & 1 \\ - & 2 & 2\end{array}$

\section{Incised-Punctated}

cross-hatched lines on lower rim and tool punctated row at rim-body juncture

diagonal lines and horizontal linear punctated

fingernail punctated rows on the rim, and horizontal incised line at the rim-body juncture

horizontal and diagonal lines and triangular zone with tool punctates

parallel lines and diagonal tool punctated row straight line and adjacent circular punctated zone

\begin{tabular}{lll}
- & 2 & 2 \\
1 & - & 1 \\
- & 1 & 1 \\
- & 1 & 1 \\
- & 2 & 2 \\
- & 1 & 1 \\
& & \\
- & 1 & 1 \\
- & & \\
2 & 2 & 2 \\
3 & 11 & 13 \\
\hline
\end{tabular}

\section{Pinched}

straight pinched ridge

Punctated

fingernail punctated rows

tool punctated rows

Totals

Also in the utility wares from the site is a Killough Pinched body sherd and a body sherd with a straight appliqued fillet (see Table 5).

The eight fine ware sherds have engraved, engraved-slipped, and red-slipped decorative elements (Table 6). The two red-slipped sherds are from Sanders Plain vessels. As redefined by Brown (1996:401403 and Figures 2-191, 2-34g, 2-37a-1, 2-38d, 2-39d, k, n-q, and 2-42b), Sanders Plain is a grog-tempered, slipped, but otherwise undecorated type found widely across the Caddo area. Vessel forms include bowls, carinated bowls, and narrow and wide-mouthed bottles. 


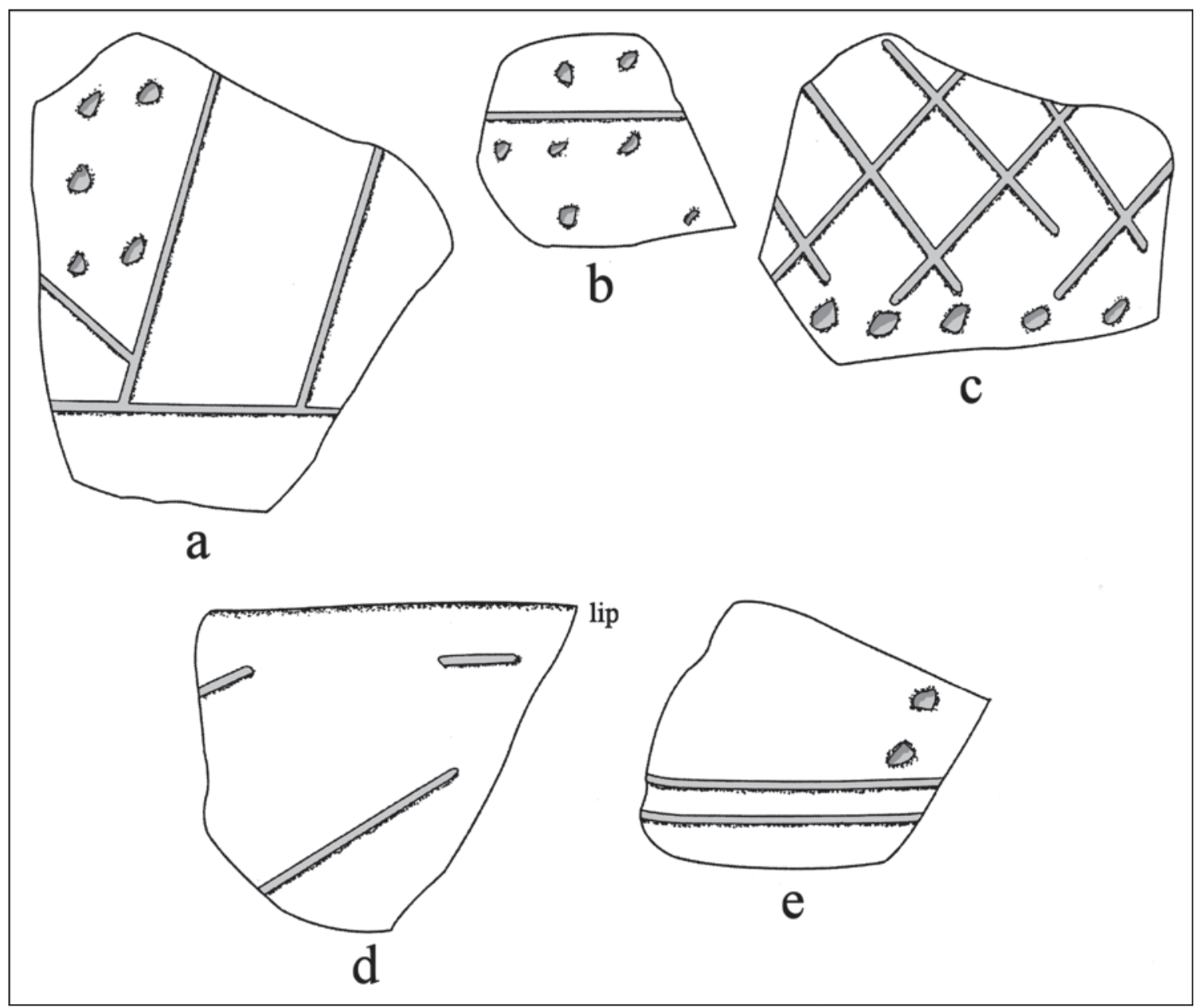

Figure 9. Incised-punctated rim and body sherds from the Highway 80 site in Wood County, Texas.

Table 6. Decorative methods/elements in the fine ware sherds from the Highway 80 site in Wood County, Texas.

Decorative method/

$\operatorname{Rim}$

Body

$\mathrm{N}$ decorative element

\section{Engraved}

diagonal opposed lines

diagonal opposed lines on int. thickened rim

horizontal and diagonal lines

horizontal and diagonal opposed lines

horizontal line and large pendant triangle filled with

curvilinear lines

Engraved-Red-Slipped

parallel lines with large hatched pendant triangles

$-1$

Red-Slipped

ext. red-slipped

$\begin{array}{ll}- & 2\end{array}$


One engraved sherd is from a Spoonbill Engraved vessel with an interior thickened rim with diagonal opposed engraved lines on the interior rim. Spoonbill Engraved vessels have been recovered from Middle Caddo period sites (ca. A.D. 1200-1400) in the upper Sabine River basin (Perttula et al. 2009). These vessels have interior thickened rims with upper and lower sets of hatched (3-4 hatched lines) engraved triangles or other engraved decorative elements. The apex of the upper and lower rows of triangles touch (Perttula and Selden 2014b:Figure 16).

Two other engraved carinated bowl sherds are from Sanders Engraved vessels (see Suhm and Jelks 1962) with diagonal opposed engraved lines (Figure 10a), while a grog-tempered body sherd from a bottle also has diagonal opposed engraved lines. A large engraved and red-slipped bottle sherd from a Sanders Engraved bottle (see Suhm and Jelks 1962:Plate 69) from the site has large hatched triangle elements.

The last engraved sherd from the Highway 80 site is a rim from a probable Poynor Engraved vessel (see Figure 10b; see also Perttula 2011b:Figure 6-64). The rim has a horizontal engraved line under the lip as well as a large engraved pendant triangle; the pendant triangle is filled with closely-spaced curvilinear engraved lines. The probable Poynor Engraved vessel sherd at the site suggests the Caddo occupation here postdated ca. A.D. 1350, the earliest manufacture dates for Poynor Engraved vessels in the upper Neches River basin in East Texas.

\section{Perryville-Indian Creek Site}

There are 11 Caddo ceramic sherds from this site in Wood County: 10 plain body and base sherds and one utility ware body sherd with multiple parallel incised lines. Approximately 90.9 percent of the sherds are from grog-tempered vessels; one of the plain body sherds is from a bone-tempered vessel.

\section{White Oak Creek Site}

Ceramic sherds were collected by Buddy Calvin Jones from this Wood County site on White Oak Creek in July 1958. There are 20 grog-tempered plain $(n=17)$ and decorated $(n=3)$ body sherds. Two utility ware body sherds have either linear tool punctations or parallel brushing marks; the presence of brushed sherds is indicative of a ca. post-A.D. 1250 Caddo occupation at the site. The one fine ware sherd has diagonal engraved lines.

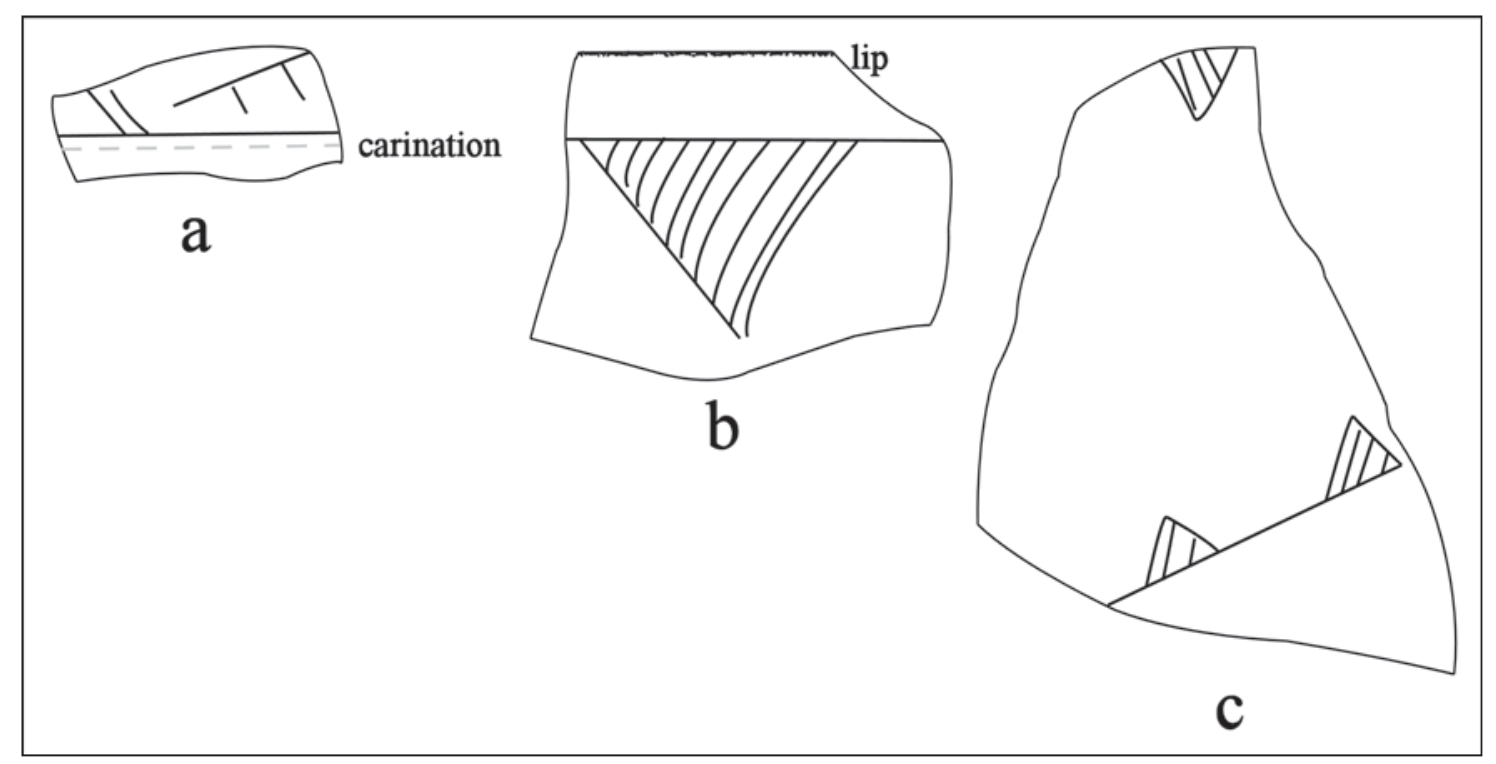

Figure 10. Selected engraved decorative elements on fine ware sherds from the Highway 80 site. 


\section{Wood County 11, Mrs. Perkins Site}

This site has 40 ceramic sherds, 95 percent from grog-tempered vessels and 5 percent from bonetempered vessels; both bone-tempered sherds are plain body sherds. The plain sherds in the collection include 31 sherds: 1 rim and 30 body sherds.

Four sherds are from utility ware vessels. These include a post-A.D. 1430 La Rue Neck Banded jar rim (see Suhm and Jelks 1962), another rim with tool punctated rows, a body sherd with rows of fingernail punctations above parallel appliqued fillets, and a body sherd with parallel incised lines adjacent to a straight appliqued ridge.

There are five sherds from fine ware vessels. One rim has a red slip on interior and exterior surfaces, two body sherds from carinated bowls have horizontal and diagonal engraved lines, and another body sherd has a straight engraved line. A bottle sherd in the collection, probably from a post-A.D. 1430 Ripley Engraved bottle, has cross-hatched triangle elements within larger triangle elements (Figure 11).

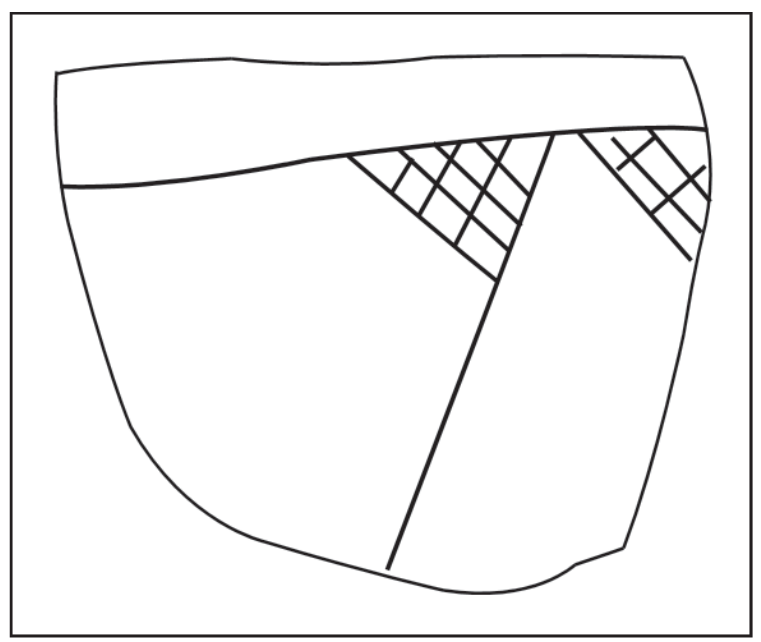

Figure 11. Engraved bottle sherd from the Mrs.

Perkins site in Wood County, Texas.

\section{Summary and Conclusions}

Buddy Calvin Jones discovered and collected from a wide variety of archaeological sites in East Texas, especially ancestral Caddo sites in the Big Cypress Creek and Sabine River basins. These Caddo sites were marked by a diverse range of ceramic vessel sherds, including sherds from plain ware, utility ware, and fine ware vessels of many forms and decorative elements, as well as chipped stone arrow points and ground stone tools. Jones' collections of sherds are now curated at the Gregg County Historical Museum in Longview, Texas.

Many of the sherd collections are from sites that have not formally been recorded with the State of Texas. Jones conducted no analyses of these sherd collections, or prepared any reports or articles on the significance of the sites from which these collections came. In this article, I report on the recent documentation of ancestral Caddo ceramic vessel sherds from 14 different sites in the Big Cypress Creek or Sabine River basins in Upshur and Wood counties, Texas. With two exceptions, the Caddo ceramic sherds are from sites that were occupied by Caddo peoples after ca. A.D. 1250; in the case of the other two sites, it is not clear when they were occupied by Caddo peoples. One site on Lake Fork Creek in Wood County has a Middle Caddo period (ca. A.D. 1200-1400) ceramic assemblage, while two other sites in the Sabine River and Little Cypress Creek basins have ceramic assemblages indicative of Late Caddo period, Titus phase (ca. A.D. 1430-1680) occupations by Caddo peoples. 


\section{Acknowledgments}

Thanks are extended to Patti Haskins, who greatly facilitated the study of the sherd collections from sites in the Buddy Jones collection at the Gregg County Historical Museum. Lance Trask prepared the figures in this article.

\section{References Cited}

Brown, J. A.

1996 The Spiro Ceremonial Center. The Archaeology of Arkansas Valley Caddoan Culture in Eastern Oklahoma. 2 Vols. Memoir No. 29. Museum of Anthropology, University of Michigan, Ann Arbor.

Dunnell, R. C.

1978 Style and Function: A Fundamental Dichotomy. American Antiquity 43(2):192-202.

Fields, R. C., V. L. Hatfield, D. Burden, E. F. Gadus, M. C. Wilder, and K. W. Kibler

2014 Testing and Data Recovery Excavations at 11 Native American Archeological Sites along the U.S. Highway 271 Mount Pleasant Relief Route, Titus County, Texas. 2 Vols. Reports of Investigations No. 168. Prewitt and Associates, Inc., Austin.

Jones, B. C.

1957 The Grace Creek Sites, Gregg County, Texas. Bulletin of the Texas Archeological Society 28:198-231.

1968 The Kinsloe Focus: A Study of Seven Historic Caddoan Sites in Northeast Texas. Master's thesis, Department of Anthropology, University of Oklahoma, Norman.

Perttula, T. K.

2000 Functional and Stylistic Analyses of Ceramic Vessels from Mortuary Features at a $15^{\text {th }}$ and $16^{\text {th }}$ Century Caddo Site in Northeast Texas. Midcontinental Journal of Archaeology 25(1): 101-151.

2006 A Study of the Buddy Jones Collection from Northeast Texas Caddo Sites. Special Publication No. 6. Friends of Northeast Texas Archaeology, Pittsburg and Austin.

2009a Caddo Sherds from the Hudnall-Pirtle Site (41RK4) in the Buddy Jones Collection at the Gregg County Historical Museum. Journal of Northeast Texas Archaeology 31:37-40.

2009b A $19^{\text {th }}$ Century Caddo Component at the Gatlin Site (41RK1) in the Angelina River Basin of East Texas. Journal of Northeast Texas Archaeology 31:41-44.

2011a Notes on the Hudnall-Pirtle Site (41RK4) in the Buddy Calvin Jones Collection at the Gregg County Historical Museum. Journal of Northeast Texas Archaeology 34:79-82.

2011b The Ceramic Artifacts from the Lang Pasture Site (41AN38) and the Place of the Site Within an Upper Neches River Basin Caddo Ceramic Tradition. In Archeological Investigations at the Lang Pasture Site (41AN38) in the Upper Neches River Basin of East Texas, assembled and edited by T. K. Perttula, D. B. Kelley, and R. A. Ricklis, pp. 145-320. Report 129, Texas Department of Transportation, Archeological Studies Program, Environmental Affairs Division, Austin.

2011c Another Look at the Grace Creek \#1 Site in Gregg County, Texas, as Seen Through Ceramic Analysis. Journal of Northeast Texas Archaeology 35:11-46.

2011d The Pipe Site, a Late Caddo Site at Lake Palestine in Anderson County, Texas. Journal of Northeast Texas Archaeology 35:47-80.

2012 Documentation of Archaeological Materials from the Cherokee Lake Site (41RK132), Rusk County, Texas. Journal of Northeast Texas Archaeology 38:21-29.

2013 Additional Ancestral Caddo Ceramic and Lithic Artifacts from the Three Mounds Creek Site, Gregg County, Texas. Journal of Northeast Texas Archaeology 40:61-63.

2014a Glade Creek at Oil Lease Grave Site, Gregg County, Texas. Journal of Northeast Texas Archaeology 44:21-22. 
2014b The Ceramic Sherd Assemblage from the Boatstone Site in Gregg County, Texas. Journal of Northeast Texas Archaeology 45:1-4.

2014c A Woodland Period Ceramic Assemblage from Rabbit Creek in the Sabine River Basin, Gregg County, Texas. Journal of Northeast Texas Archaeology 45:5-7.

2014d The Caddo Ceramics from Three Sites on Hawkins Creek in the Sabine River Basin, Gregg County, Texas. Journal of Northeast Texas Archaeology 45:23-30.

2014e The Sipes' Home Site (41RK603): A Late $18^{\text {th }}$ to Early $19^{\text {th }}$ Century Caddo Site on Martin Creek in Rusk County, Texas. Journal of Northeast Texas Archaeology 45:31-37.

2016a An Artifact Assemblage from Area B at the Grace Creek Site (41GG33), Gregg County, Texas. Journal of Northeast Texas Archaeology 61:11-15.

2016b Ceramic Sherds from the Millsey Williamson Site (41RK3), Rusk County, Texas. Journal of Northeast Texas Archaeology 61:17-20.

2016c Caddo Ceramic Assemblage from a Site Across the Road from the Millsey Williamson Site in Rusk County, Texas. Journal of Northeast Texas Archaeology 61:21-27.

2016d An Ancestral Caddo Site on Mill Creek in Rusk County, Texas. Journal of Northeast Texas Archaeology 61:29-33.

2016e Ceramic Sherd Assemblage from the Cherokee Lake Site (41RK132), Rusk County, Texas. Journal of Northeast Texas Archaeology 61:35-38.

$2016 \mathrm{f}$ Caddo Ceramic Sherd Assemblage from a Hearth Feature at the Cherokee Lake Site (41RK132) in Rusk County, Texas. Journal of Northeast Texas Archaeology 61:39-43.

2016g The Oil Road Site in Rusk County, Texas. Journal of Northeast Texas Archaeology 61:45-49.

2015h The E. Williams Site on Martin Creek in Panola County, Texas. Journal of Northeast Texas Archaeology 61:51-54.

Perttula, T. K. and B. Nelson

2007 Documentation of a Collection of Archaeological Materials from the Millsey Williamson Site (41RK3), a Historic Nadaco Caddo Settlement. Journal of Northeast Texas Archaeology 26:120-127.

2013a Two Middle Caddo Period Habitation Sites and Cemeteries in the Sabine River Basin, Gregg County, Texas. Special Publication No. 27. Friends of Northeast Texas Archaeology, Pittsburg and Austin.

2013b A Frankston Phase Settlement and Cemetery at the H. C. Slider Site on the Neches River in Cherokee County, Texas. Journal of Northeast Texas Archaeology 41:41-56.

2014a A Whole Vessel from the Henry Brown \#2 Site (41HS262), a Historic Nadaco Caddo Site in Harrison County, Texas. Journal of Northeast Texas Archaeology 44:17-19.

2014b The Millsey Williamson (41RK3), Bead Burial, and L. N. Morwell Farm Sites on Martin Creek: Historic Caddo Settlements along Trammels Trace, Rusk County, Texas. Journal of Northeast Texas Archaeology 44:23-46.

2014c Caddo Ceramic Vessels from the Mrs. Martin Farm, Harrison County, Texas. Journal of Northeast Texas Archaeology 44:47-50.

2014d The Clay Ball Site in the Upper Neches River Basin of East Texas. Journal of Northeast Texas Archaeology 44:75-83.

2014e Caddo Ceramic Vessels from the Loftis and Pearl Smith Sites in Harrison County, Texas. Journal of Northeast Texas Archaeology 45:63-66.

Perttula, T. K. and R. Z. Selden Jr.

2014a Glass Beads from Kinsloe Focus Sites in Gregg, Harrison, and Rusk Counties, Texas. Journal of Northeast Texas Archaeology 44:51-73.

2014b Ancestral Caddo Ceramics in East Texas. Journal of Northeast Texas Archaeology 48:9-58. 
Perttula, T. K., B. Nelson, and R. Z. Selden, Jr.

2013a Documentation of Cemeteries and Funerary Offerings from Sites in the Upper Neches River Basin, Anderson, Cherokee, and Smith Counties, Texas. Special Publication No. 26. Friends of Northeast Texas Archaeology, Pittsburg and Austin.

Perttula, T. K., B. Nelson, and M. Walters

2012a Caddo Archaeology at the Henry Spencer Site (41UR315) in the Little Cypress Creek Basin of East Texas. Special Publication No. 20. Friends of Northeast Texas Archaeology, Pittsburg and Austin.

Perttula, T. K., R. Z. Selden, Jr., and B. Nelson

2013b Analysis of the Ceramic Sherds from Area C at the Ware Acres Site (41GG31), Gregg County, Texas. Journal of Northeast Texas Archaeology 41:57-79.

2014a Documentation of Unassociated Ceramic Vessel Funerary Objects in the Gregg County Historical Museum Collections from Sites in Gregg, Harrison, and Panola Counties in East Texas. Special Publication No. 29. Friends of Northeast Texas Archaeology, Pittsburg and Austin.

2014b A Catalog of Selected Caddo Ceramic Vessels in the Buddy Jones Collection at the Gregg County Historical Museum. Special Publication No. 30. Friends of Northeast Texas Archaeology, Pittsburg and Austin.

2014c Documentation of Ceramic Vessels and Projectile Points from the C. D. Marsh Site (41HS269) in the Sabine River Basin. Journal of Northeast Texas Archaeology 44:85-98.

2014d Caddo Ceramic Vessels from the Sipes Hill Site (41RK602) along Martin Creek in the Sabine River Basin in East Texas. Journal of Northeast Texas Archaeology 45:9-21.

2014e Archaeological Investigations at the Wade (GC-38) and Estes (GC-49) Sites in the Sabine River Basin, Gregg County, Texas. Journal of Northeast Texas Archaeology 45:39-61.

Perttula, T. K., M. Walters, and P. Haskins

2015 The Ceramic Sherd Assemblage from the C. D. Marsh Site (41HS269) in Harrison County, Texas. Journal of Northeast Texas Archaeology 61:55-64.

Perttula, T. K., M. Walters, and B. Nelson

2012b Little Cypress Creek Basin Archaeology: Six Late Caddo Period Cemeteries in Upshur County, Texas. Special Publication No. 22. Friends of Northeast Texas Archaeology, Pittsburg and Austin.

2012c Early 1960s Excavations at the Sam Kaufman Site (41RR16), Red River County, Texas. Journal of Northeast Texas Archaeology 36:1-31.

2012d The Younger Site (41MR6), Marion County, Texas. Journal of Northeast Texas Archaeology 38:1-20.

Perttula, T. K., M. Walters, S. Marceaux, and B. Nelson

2009 Caddo Pottery Vessels and Pipes from Sites in the Middle and Upper Sabine and Upper Neches River Basins, Smith and Wood Counties, Texas. Special Publication No. 7. Friends of Northeast Texas Archaeology, Pittsburg and Austin.

Rice, P. M.

1987 Pottery Analysis: A Sourcebook. University of Chicago Press, Chicago.

Schambach, F. F., J. C. Weber, and A. N. Early

n.d. Typology and Nomenclature for South Arkansas Ceramics, Part II: The Descriptive Classification. MS on file, Arkansas Archeological Survey, Fayetteville.

Suhm, D. A. and E. B. Jelks (editors)

1962 Handbook of Texas Archeology: Type Descriptions. Special Publication No. 1, Texas Archeological Society, and Bulletin No. 4, Texas Memorial Museum, Austin.

Webb, C. H.

1959 The Belcher Mound, a Stratified Caddoan Site in Caddo Parish, Louisiana. Memoirs No. 16. Society for American Archaeology, Salt Lake City. 